\title{
Watershed Scale Response to Climate Change-Sprague River Basin, Oregon
}

\section{Introduction}

General Circulation Model (GCM) simulations of future climate through 2099 project a wide range of possible scenarios (Intergovernmental Panel on Climate Change, 2007). To determine the sensitivity and potential effect of long-term climate change on the freshwater resources of the United States, the U.S. Geological Survey Global Change study, "An integrated watershed scale response to global change in selected basins across the United States" was started in 2008. The long-term goal of this national study is to provide the foundation for hydrologically based climate-change studies across the nation.

Fourteen basins for which the Precipitation Runoff Modeling System (PRMS) has been calibrated and evaluated were selected as study sites. PRMS is a deterministic, distributedparameter watershed model developed to evaluate the effects of various combinations of precipitation, temperature, and land use on streamflow and general basin hydrology. Output from five GCMs and four emission scenarios were used to develop an ensemble of climate-change scenarios for each basin. These ensembles were simulated with the corresponding PRMS model. This fact sheet summarizes the hydrologic effect and sensitivity of the PRMS simulations to climate change for the Sprague River Basin near Chiloquin in Oregon (U.S. Geological Survey streamflow-gaging station 11501000; fig. 1) presented in the project summary report (Markstrom and others, 2012) and a journal article (Hay and others, 2011).

\section{Study Area}

The Sprague River is located in the northeastern headwaters of the Klamath River and drains a semiarid basin of 4,053 square kilometers $\left(\mathrm{km}^{2}\right)$. Mean annual precipitation (1961-1990), spatially averaged over the basin, is 51 centimeters. Snowfall comprises about 30 and 50 percent of annual precipitation in the valley lowlands and the higher elevations, respectively. The Sprague River flows to the west draining inactive volcanoes, rims, scarps, buttes, and fault-block mountains along the northern, eastern, and southern basin boundaries. Elevations in the Sprague River Basin range from 1,280 to 2,530 meters. Lower elevation benches and tablelands are used as rangeland; bottomlands along the mainstream and major tributaries are used for irrigated agriculture. Conifer forests, which cover approximately 80 percent of the basin area, are predominant on the slopes of buttes and mountains.

Streamflow has been continuously measured near the mouth of the basin for more than 85 years (U.S. Geological Survey streamflow-gaging station 11501000) and has a period of record average discharge of 16 cubic meters per second. The Sprague River Basin supplies approximately 25 percent of total inflow to the Upper Klamath Lake. Demand for water from the lake has increased in recent years in response to needs such as irrigated agriculture, minimum downstream flow for threatened coho salmon, water supply for nearby wildlife refugees, hydropower, and a minimum lake level for habitat and water-quality protection of two endangered sucker species. The PRMS model used in this study is further described in Hay and others (2009).

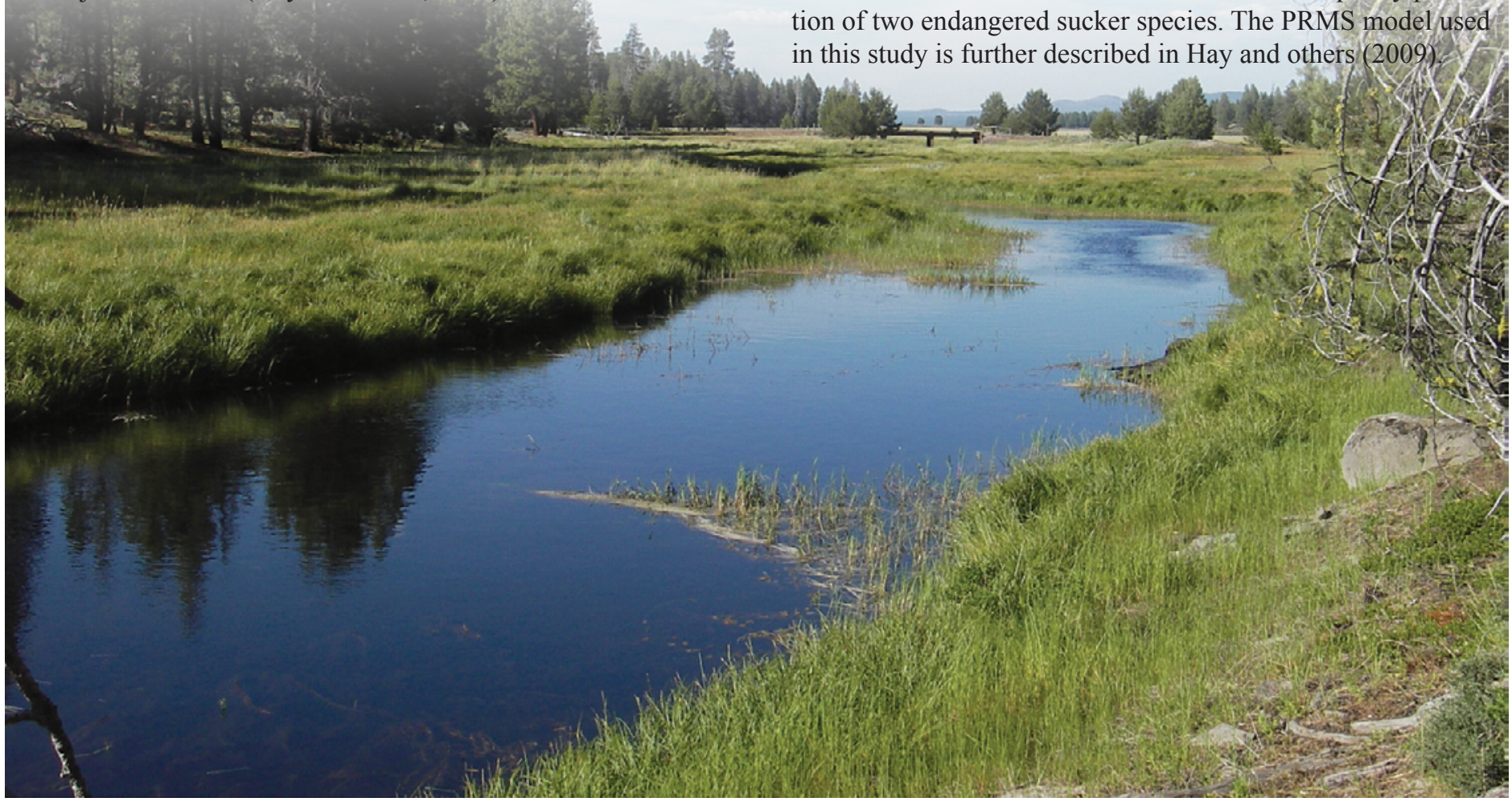



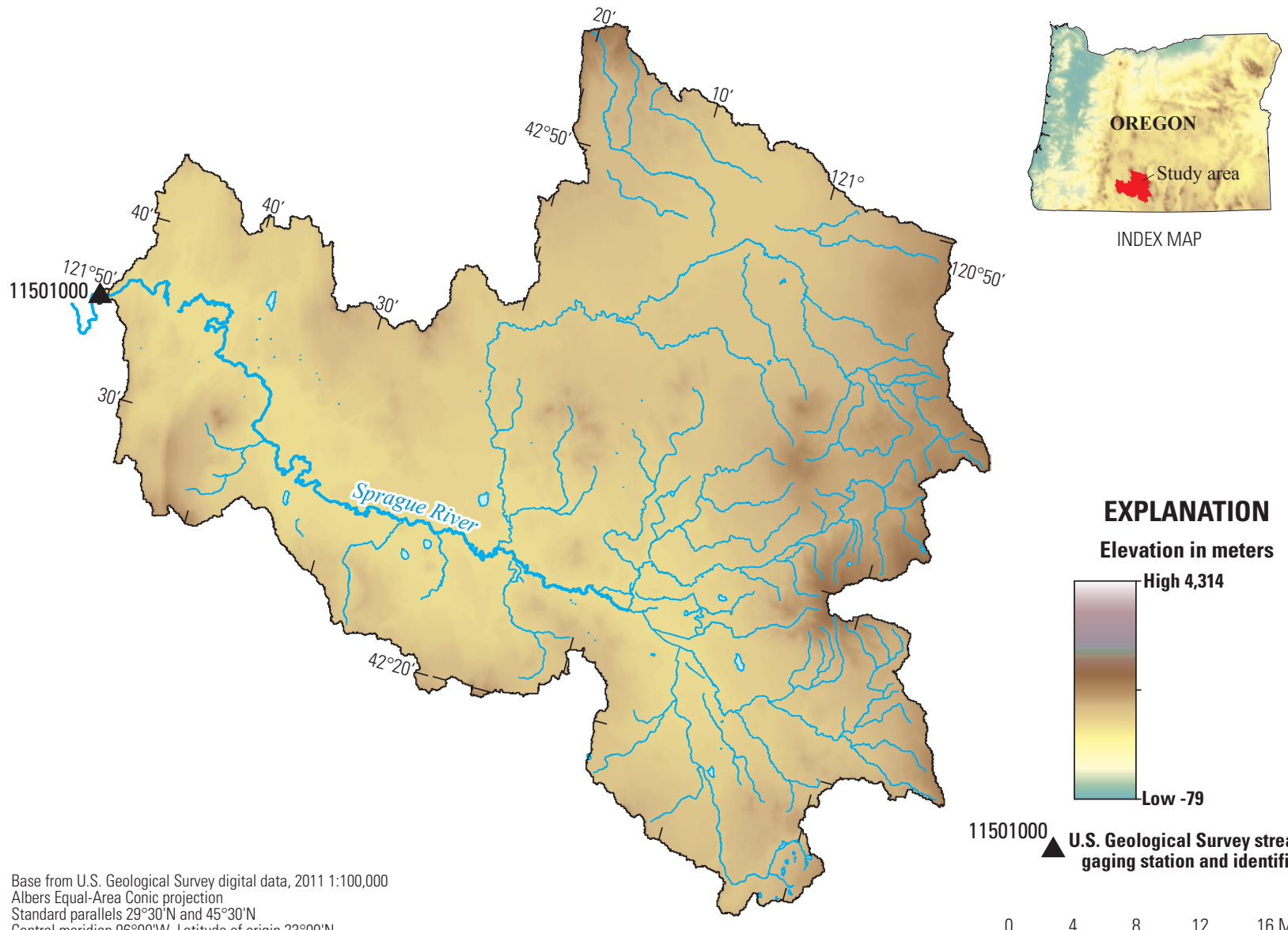

INDEX MAP

\section{EXPLANATION}

Elevation in meters

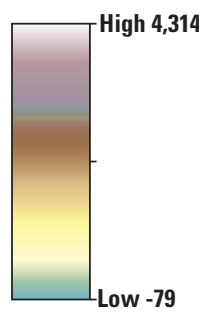

11501000

U.S. Geological Survey streamflowgaging station and identifier

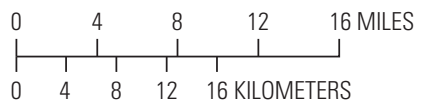

Horizontal coordinate information is referenced to the World Geodetic System of 1984 (WGS 84)

Figure 1. Precipitation Runoff Modeling System study locations, Sprague River Basin, Oregon, and location of U.S. Geological Survey streamflow-gaging station 11501000 with a drainage area of 4,053 square kilometers and elevation range from 1,316 to 2,203 meters.

\section{General Circulation Models}

Given the uncertainty in climate modeling, it is desirable to use more than one GCM to obtain a range of potential future climatic conditions. Monthly precipitation and temperature output from five GCMs was processed (table 1).

Table 1. General Circulation Model (GCM) projections used in this study.

\begin{tabular}{ll}
\hline \multicolumn{1}{c}{ GCM } & \multicolumn{1}{c}{ Center and country of origin } \\
\hline BCC-BCM2.0 & Bjerknes Centre for Climate Research, Norway \\
CSIRO-Mk3.0 & Australia's Commonwealth Scientific and Industrial Research Organization, Australia \\
CSIRO-Mk3.5 & Australia's Commonwealth Scientific and Industrial Research Organization, Australia \\
INM-CM3.0 & Institute for Numerical Mathematics, Russia \\
MIROC3.2 & National Institute for Environmental Studies, Japan \\
\hline
\end{tabular}


The GCM outputs were obtained from the World Climate Research Programme's Coupled Model Intercomparison Project phase 3 multi-model dataset archive, which was referenced in the Intergovernmental Panel on Climate Change Fourth Assessment Special Report on Emission scenarios (Intergovernmental Panel on Climate Change, 2007). For each GCM, one current (water years 1988-1999) and three future emission scenarios were used and are described in table 2.

Table 2. Climate-change emission scenarios simulated by the General Circulation Models in this study.

\begin{tabular}{ll}
\hline \multicolumn{1}{c}{ Emission scenario } & \multicolumn{1}{c}{ Description/assumptions } \\
\hline 20C3M & $\begin{array}{l}\text { 20th century climate used to determine baseline (1989-1999) conditions } \\
\text { Rapid economic growth, a global population that peaks in mid-21st century and rapid introduction of new and } \\
\text { more efficient technologies with a balanced emphasis on all energy sources } \\
\text { Convergent world, with the same global population as Emission scenario A1B, but with more rapid changes in } \\
\text { economic structures toward a service and information economy that is more ecologically friendly } \\
\text { B1 }\end{array}$ \\
Heterogeneous world with high population growth, slow economic development, and slow technological change \\
\hline
\end{tabular}

Climate-change fields were derived by calculating the change in climate from current (water years 1988-1999) to future conditions simulated by each GCM. The 20C3M simulation for water years 1988-1999 was used to represent current climatic conditions. This 12 -year period of record was chosen based on the overlap of the available historical records from the 14 basins included in the national study. Climate change fields (percentage changes in precipitation and degree changes in temperature) were computed for 12-year moving window periods (from 2001-2099) using the 20C3M (1988-1999) and the $\mathrm{A} 1 \mathrm{~B}, \mathrm{~B} 1$, and $\mathrm{A} 2$ emission scenarios. A 12-year moving window, starting in 2001 and ending in 2099, results in 1,320 future scenarios $[(88,12$-year climatologies, 1 per year starting with 2001-2012 and ending with 2088-2099) x (3 emission scenarios) x (5 GCMs)].

Climate-change scenarios were generated for PRMS by modifying PRMS precipitation and temperature inputs with the mean monthly climate change fields derived from the GCMs, resulting in 1,320 PRMS-input files. Table 3 shows the change (slope) and adjusted $\mathrm{R}^{2}$ (adjR2) for the least squares fit to the trend line for selected output variables from the PRMS projections. The slope indicates the change in the selected variable by year. The adjusted $\mathrm{R}^{2}$ value gives an indication of the variability in the central tendency of the trend line.

Figure 2 shows a summary of the projected range in 11-year moving mean daily values of maximum temperature (fig. $2 A$ ), minimum temperature (fig. $2 B$ ), and precipitation (fig. $2 C$ ) by emission scenario. The first year of each 12-year simulation was used as PRMS initialization and is not included in the results. The three solid-colored lines indicate the 11-year moving mean values (x-axis indicates center of 11 -year window) for the three future emission scenarios (central tendency of the five GCMs for each emission scenario). The projected range shown for each emission scenario indicates the range of potential future climatic conditions simulated by the five GCMs. All GCM simulations project steady increases in maximum and minimum temperature (table 3), with uncertainties associated with these GCM projections increasing with time. Both maximum and minimum temperatures show the smallest projected changes for the B1 emission scenario. Mean annual projections in precipitation are highly variable with the range in projections showing both increases and decreases in projected precipitation. The lines of central tendency project a significant overall positive trend in precipitation for the A1B emission scenario only (table 3 ). The wide range in the precipitation projections indicates a large amount of uncertainty.

\section{Results}

PRMS simulates spatially distributed streamflow, components of flow (surface, subsurface, and groundwater), snowpack conditions, and many other hydrologic components of interest. Figure 3 shows the projected range in 11-year moving mean daily values of streamflow (fig. $3 A$ ) and the component of flow (figs. $3 B-3 D$ ) by emission scenario. Mean annual projections in streamflow are highly variable with the range in projections showing both increases and decreases in mean annual streamflow. The lines of central tendency for the three emission scenarios project no overall discernable trend in mean annual streamflow (table 3). The lines of central tendency in mean annual surface runoff project a significant overall positive trend for the A1B and A2 emission scenarios (table 3), whereas no discernable overall trend is projected for the subsurface and groundwater-flow components (the dominant flow components, table 3).

Figure 4 shows a summary of the projected annual basin mean values of evapotranspiration. The lines of central tendency in mean annual evapotranspiration project a significant overall positive trend for the A1B emission scenario only (table 3 ). This positive trend combined with the highly variable projected increases in precipitation (fig. 2 C) lead to the highly variable projections in mean annual streamflow with no significant trend over time (fig. $3 A$ ).

Projections of streamflow can be examined on a monthly basis to determine if the timing of peak runoff is expected to change (fig. 5). The red lines in figure 5 show PRMS-simulated mean monthly baseline conditions (1989-1999) for basin mean streamflow. The boxplots represent the range in the mean 

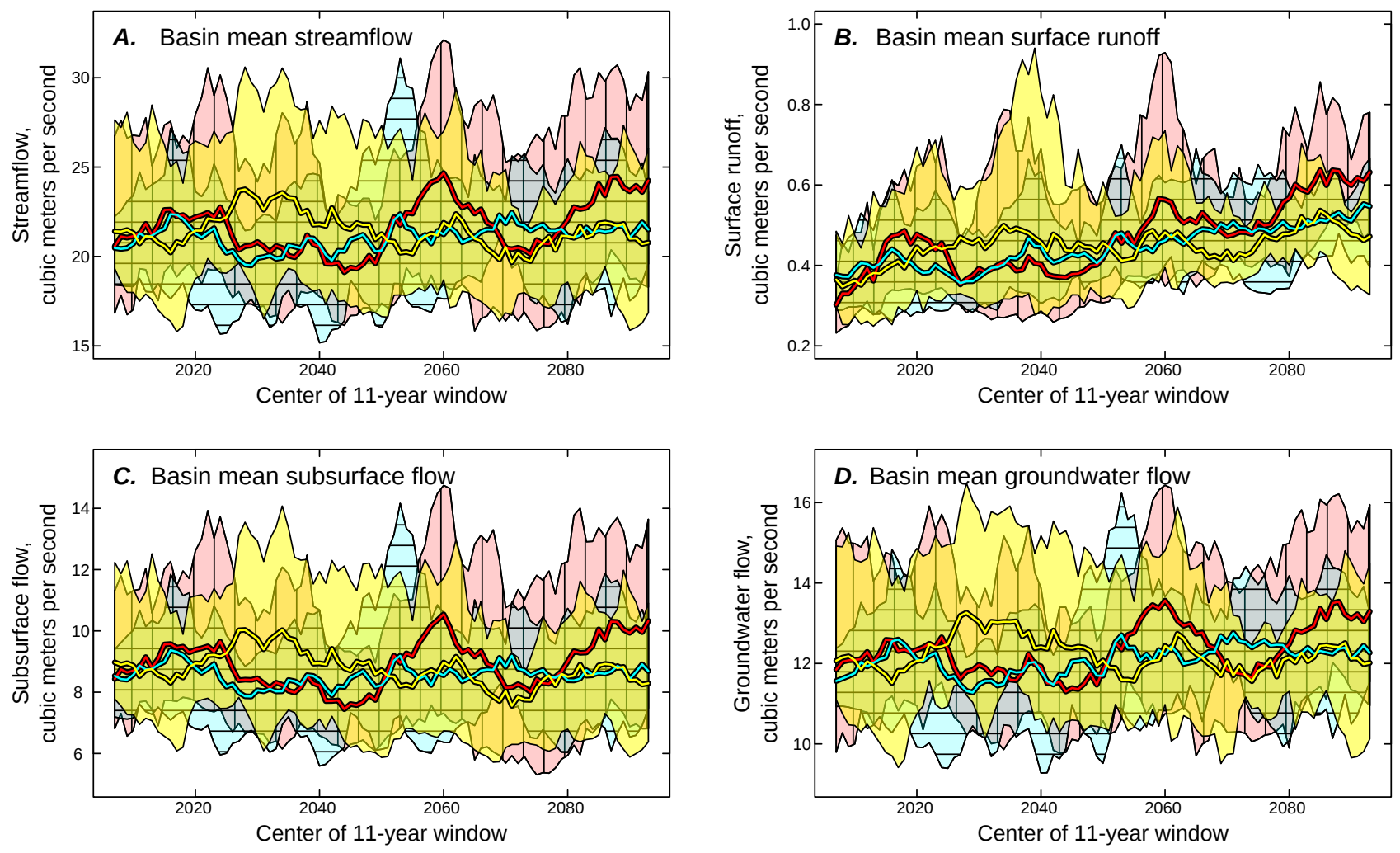

Figure 3. Projected range in 11-year moving mean daily values of $(A)$ streamflow, $(B)$ surface runoff, $(C)$ subsurface flow, and $(D)$ groundwater flow by emission scenario.

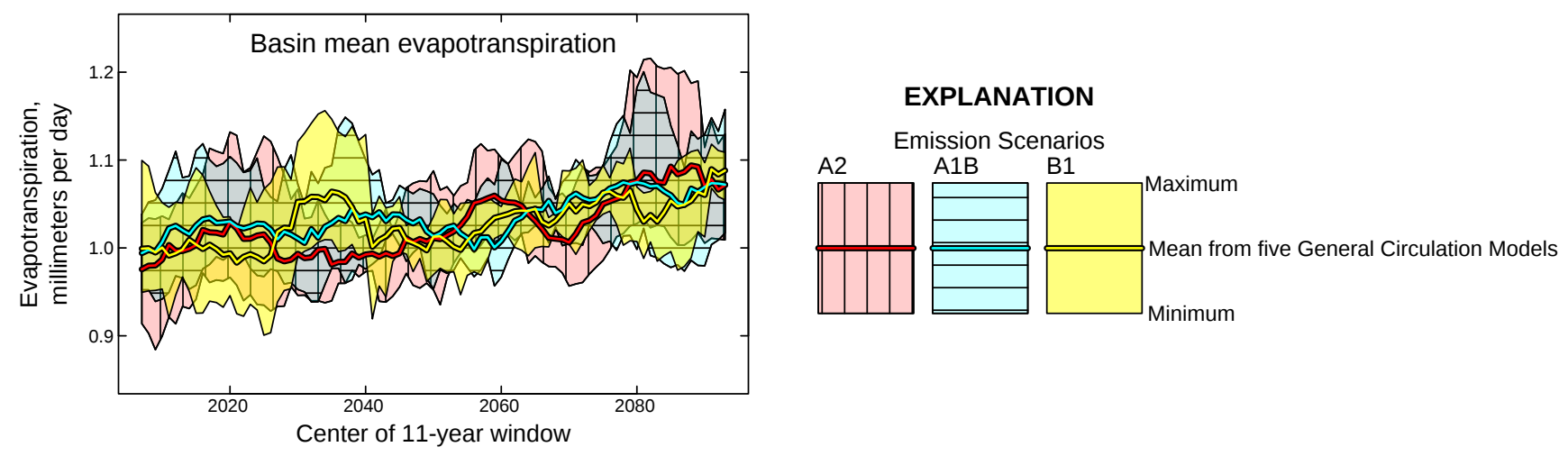

Figure 4. Projected range in 11-year moving mean daily values of evapotranspiration by emission scenario.
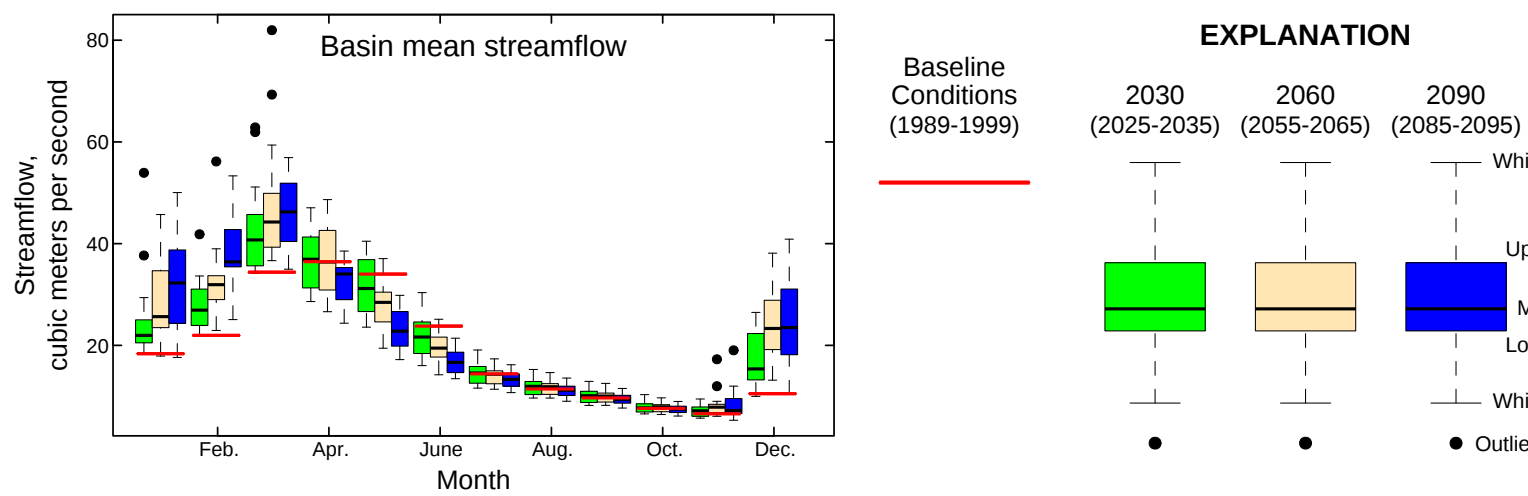

(1989-1999) (2025-2035) (2055-2065) (2085-2095)

Figure 5. Mean daily streamflow values by month for baseline conditions and projected range $(2030,2060$, and 2090$)$ using the five General Circulation Models and three emission scenarios. 


\section{Conclusion and Discussion}

Supplying approximately 25 percent of inflow to Upper Klamath Lake, the Sprague River Basin is vital to environmental and human water needs within the Klamath River Basin. As water demands increase, the reliability of flows from headwater basins like the Sprague becomes increasingly critical in watermanagement decisions. The broader scale effects of climate change on the flow regime of the Sprague River indicates increased annual high flows occurring earlier in the spring as overall basin storage decreases. However, the uncertainty associated with these changes is large. It is apparent that with significant changes in seasonal patterns of inflow to Upper Klamath Lake, one or a combination of the following measures may be necessary: (1) modification of the operation of the lake as a storage reservoir, (2) creation of additional storage capacity to meet water demands, and (3) reprioritization of water deliveries for environmental and human needs.

The scientific techniques described in the fact sheet can be augmented with other techniques in developing the science needed to address the effects of climate change on the streamflow regime.

\section{Selected References}

Hay, L.E., McCabe, G.J., Clark, M.P., and Risley, J.C., 2009, Reducing streamflow forecast uncertainty: Application and qualitative assessment of the upper Klamath River basin, Oregon: Journal of the American Water Resources Association, v. 45, (no. 3), p. 580-596.

Hay, L.E., Markstrom, S.L., and Ward-Garrison, C.D., 2011, Watershed-scale response to climate change through the twenty-first century for selected basins across the United States, Earth Interactions, v. 15, 37 p.

Intergovernmental Panel on Climate Change, 2007, Summary for policymakers, in Climate change 2007-The physical science basis, Contributions of Working Group 1 to the Fourth Assessment Report of the Intergovernmental Panel on Climate Change: Cambridge and New York, Cambridge University Press, $18 \mathrm{p}$.

Markstrom, S.L., Hay, L.E., Ward-Garrison, C.D., Risley, J.C., Battaglin, W.A., Bjerklie, D.M., Chase, K.J., Christiansen, D.E., Dudley, R.W., Hunt, R.J., Koczot, K.M., Mastin, M.C., Regan, R.S., Viger, R.J., Vining, K.C., and Walker, J.F., 2012, An integrated watershed scale response to climate change for selected basins across the United States: U.S. Geological Survey Scientific Investigations Report 2011-5077, 142 p.

By John Risley, Lauren E. Hay, and Steven L. Markstrom For more information visit the following Web sites:

http://wwwbrr.cr.usgs.gov/projects/SW_MoWS/

http://or.water.usgs.gov/klamath/index.html/

http://www.usgs.gov/climate_landuse/ 